\title{
NAMULISKA JASKINIOWE WE WSPÓŁCZESNYM KRAJOZNAWSTWIE POLSKIM - SPOŁECZNA ZNAJOMOŚĆ ZAGADNIENIA
}

\section{Wprowadzenie}

Świadomość istnienia namulisk jaskiniowych (osadów okruchowych wypełniających jaskinie) jest w społeczeństwie znikoma. Brak znajomości tematu ujawnia się podczas prywatnych rozmów z różnymi osobami spoza społeczności speleologów i grotołazów. Wpływ na taki poziom wiedzy ma marginalne traktowanie zagadnienia w mediach, książkach i programie nauczania szkolnego. Jaskinia jest zazwyczaj postrzegana poprzez pryzmat pustki w skale, charakterystycznego elementu krajobrazu, w jakim występuje, szaty naciekowej oraz nieodłącznej ciemności i tajemniczości, czasem niebezpieczeństwa. Wydaje się, że obecność osadów klastycznych i organogenicznych w jaskiniach oraz tego, co się w nich znajduje, jest przez turystów znana marginalnie lub wcale.

W krajoznawstwie i turystyce namuliska stanowią jednak potencjalnie ważne obiekty, ze względu na znaczne walory naukowe i historyczne. Informacje zdobyte dzięki badaniu namulisk są postrzegane jako ciekawe. Tak odbierane są np. dane dotyczące sposobu życia neandertalczyków lub wyglądu wymarłych zwierząt plejstoceńskich. Namuliska trzeba jednak uznać za nieatrakcyjne do zwiedzania, gdyż są niewidoczne i niedostępne, czasem zakryte chodnikiem, a umożliwiające wgląd wykopy badawcze zazwyczaj są zabezpieczone i zasypane. A w sytuacji, gdy takie wykopy istnieja, nie udostępnia się ich turystom ze względów bezpieczeństwa. Pochodzące z namulisk znaleziska, choć interesujące (np. kości niedźwiedzia jaskiniowego, krzemienne pięściaki), słabo nadają się do wyeksponowania. Zwykle są to bowiem obiekty nieduże, których nie można zostawić 
niestrzeżonych. Ponadto zazwyczaj przechowuje się je w kolekcjach muzealnych lub naukowych, w odległych od jaskiń ośrodkach.

Świadomi istnienia i budowy namulisk są grotołazi, którzy często kopią w osadach jaskiniowych w poszukiwaniu ukrytych korytarzy. Jest to działanie szkodliwe z naukowego punktu widzenia, które wynika m.in. z niepełnej świadomości walorów naukowych namulisk.

\section{Cel badań}

Ogólne wnioski na temat wiedzy o namuliskach jaskiniowych, które autor przedstawił powyżej, opierają się na jego osobistym doświadczeniu. Odpowiadając na zaproszenie do wzięcia udziału w Kongresie Krajoznawstwa Polskiego, autor zadał sobie pytanie o obiektywność tej opinii i o sposób jej naukowej weryfikacji. W celu obiektywnego rozpoznania znajomości jaskiń w społeczeństwie, zdecydowano się na przeprowadzenie ankiety wśród rożnych grup społecznych, w miarę możliwości szeroko reprezentujących polskie społeczeństwo. Wszystkie badane osoby otrzymały ankietę z identycznym zestawem pytań.

\section{Sposób przeprowadzenia badania}

Badanie przeprowadzono przy użyciu ankiety, dwustronicowy formularz składał się z trzech części. Pierwsza zawierała pytania pozwalające przypisać ankietowanych do grup wiekowych i społecznych (pytania o wiek, wykształcenie i zawód). Druga część to pytanie „Czy byłaś/-eś kiedyś w jaskini?", pozwalające zorientować się, czy wiedza o jaskiniach jest powiązana $z$ faktycznym ich odwiedzaniem. Trzecia i zasadnicza część to 17 pytań dotyczących różnych aspektów wiedzy o jaskiniach - $\mathrm{w}$ tym zagadnienia dotyczące bezpośrednio lub pośrednio namulisk jaskiniowych, jak i ogólnej wiedzy o jaskiniach.

Ankiety były rozprowadzane wśród różnych grup, do których autor mógł dotrzeć bezpośrednio lub dzięki pomocy zaangażowanych osób. Grupy te obejmowały m.in.: uczniów szkolnych, studentów, nauczycieli, turystów, pracowników naukowych Instytutu Nauk Geologicznych PAN oraz osoby przypadkowe. Łącznie zebrano 87 ankiet, z czego 18 zostało wypełnionych przez uczniów szkolnych, 14 przez osoby w różnym wieku o wykształceniu średnim lub zawodowym i 52 przez osoby o wykształceniu wyższym, w tym 12 to osoby posiadające stopień naukowy. 


\section{Ogólne wyniki ankiety}

Wyniki analizy ankiet pokazuja, że większość respondentów była kiedyś w jaskini (83\% spośród osób, które udzieliły odpowiedzi na to pytanie). Wynika $\mathrm{z}$ tego, że turystyka jaskiniowa jest w Polsce dość dobrze rozwinięta. Wśród osób, które nigdy nie były w jaskini, połowa to uczniowie. W przedziale wiekowym 10-20 lat liczba respondentów, którzy zwiedzali już jaskinie, dwukrotnie przewyższała liczbę osób, które jaskiń jeszcze nie odwiedziły. Można więc przyjąć, że większość osób odwiedziła jaskinie jeszcze w wieku szkolnym. Zapewne niepoślednią rolę pełnią w tym względzie wycieczki szkolne i kolonijne. $\mathrm{W}$ odpowiedzi na pytanie o znaną nazwę jaskini najwięcej osób wymieniło Jaskinię Raj i Grotę Łokietka. Pozostałe znane ankietowanym jaskinie to: Jaskinia Nietoperzowa, Jaskinia Niedźwiedzia, Jaskinia Ciemna i Jaskinia Mroźna. Wszystkie te miejsca są udostępnione dla ruchu turystycznego i zwiedzane z przewodnikiem.

Większość odpowiedzi udzielonych w ankiecie jest zgodna z naukową wiedzą o jaskiniach, co wskazuje na dobrą znajomość badanych turystów zagadnień związanych z jaskiniami. Szczególne znaczenie miały dla autora odpowiedzi na pytania dotyczące namulisk jaskiniowych - co omówiono w kolejnych częściach artykułu.

\section{Znajomość terminu „namulisko jaskiniowe”}

Celem sprawdzenia jaka jest znajomość terminu „namulisko jaskiniowe”, w ankiecie zapytano "Co to jest namulisko jaskiniowe?". Należy w tym miejscu wyjaśnić, że jest to pojęcie szeroko stosowane w polskiej literaturze naukowej i w żargonie speleologicznym, choć nie przez wszystkich badaczy akceptowane. Termin ten oznacza ogół osadów wypełniających jaskinię, przede wszystkim klastycznych i organogenicznych, choć można do tej grupy zaliczać też stalagmity i inne nacieki tworzące się na dnie jaskini. Są to najczęściej gliny pylaste bądź piaszczyste z różną zawartością gruzu (Encyklopedia PWN, 2021; Migoń, 2006; Szelerewicz, Górny, 1986). Ze względów słowotwórczych termin ten może być mylący, gdyż „namulisko” wywodzi się od namulania, co jest powszechnie rozumiane jako nanoszenie mułu lub innego drobnego materiału przez wodę. Tymczasem jest to tylko jeden z wielu czynników depozycyjnych, które prowadzą do powstawania osadów jaskiniowych. Innymi są np.: odpadanie gruzu od sklepienia i ścian jaskini oraz jego dalsza dezintegracja, wietrzenie chemiczne in situ i gromadzenie się jego produktów 
w formie ilastego rezyduum, nawiewanie lessu, a czasem też liści, a także czynniki biogeniczne i antropogeniczne. W związku z tym niektórzy badacze uważaja że termin "namulisko” jest nietrafiony i powinno się zastąpić go innym określeniem (Madeyska-Niklewska, 1969). Tak oto np. archeolog S. Krukowski, a za nim geolog T. Madeyska zaproponowali stosowanie terminu „wypełnisko” („,pełnisko"), jako lepiej oddającego naturę osadów jaskiniowych (Krukowski, 1939; Madeyska, 1988). Jest to też dokładniejsze tłumaczenie angielskiego odpowiednika cave fill. Propozycja ta nie spotkała się jednak z szerokim zainteresowaniem i termin „namulisko" jest nadal powszechnie używany w środowisku speleologów i grotołazów.

Z analizy ankiet wynika, że ponad $20 \%$ osób nie słyszało określenia „namulisko jaskiniowe”. Pozostałe osoby zaznaczyły jedną z odpowiedzi do wyboru (większość osób) lub podały własną odpowiedź (tylko jeden przypadek). Najczęściej wybieraną odpowiedzią (49\% ankietowanych) była: „muł namyty do jaskini, np. podczas powodzi”. Jest to interpretacja zgodna z ogólnym semantycznym wrażeniem, jakie wywiera to słowo. Oznacza to, że większość osób ma kłopot ze zrozumieniem znaczenia tego słowa i nie zna jego definicji. Kolejne $33 \%$ uznało, że namulisko to "glina osadzona w jaskini", co jest znacznie bliższe naukowemu znaczeniu tego terminu. Ponadto jeden ankietowany zaznaczył odpowiedź „stalaktyty i stalagmity", która odbiega od naukowego znaczenia bądź przynajmniej bardzo je zawęża; również jeden respondent udzielił własnej odpowiedzi: „,stalaktyty, stalagmity, glina, gruz, kości”, którą należy uznać za naukowo poprawną.

Wyniki ankiety wyraźnie pokazuja, że termin „namulisko” nie jest dobrze znany i właściwie rozumiany przez badanych, a ponadto rozumieją go przede wszystkim w sposób dosłowny, wynikający z budowy słowotwórczej i historii słowa. Skłania to do refleksji nad słusznością wysuniętej przez T. Madeyską i innych badaczy propozycji zastąpienia tego terminu innym, bardziej jednoznacznym. Obecnie omawiany termin jest używany przede wszystkim przez dwie grupy społeczne:

- naukowców-speleologów zajmujących się badaniami w jaskiniach, w tym głównie archeologów, paleontologów i sedymentologów, którzy mają bezpośrednio do czynienia z namuliskami;

- grotołazów, którzy zaadaptowali terminologię speleologów.

Zmiana oficjalnej terminologii i żargonu, stosowanych przez te grupy, wymagałaby intensywnej akcji edukacyjnej, zapewne w formie szkoleń oraz ogólnie dostępnego podręcznika, który pozwoliłby na utrwalenie słownictwa. 


\section{Znajomość budowy namulisk}

W ankiecie zamieszczono również pytanie o budowę namuliska. Aby nie wprawiać respondentów w zakłopotanie, jakie może spowodować nieznany termin „,namulisko”, pytanie zostało sformułowane: „Z czego zbudowane jest dno jaskini?". Poprzedzono je dwoma podobnymi zapytaniami o budowę stalaktytów i stalagmitów oraz o budowę ścian jaskini. Odpowiedzi na te dwa pytania były konsekwentne. Stalagmity i stalaktyty są według ankietowanych zbudowane ze skały wapiennej bądź z minerałów. Jako budulec ścian jaskini $2 / 3$ ankietowanych wskazało skałę wapienną. Odpowiedzi na pytanie o budowę dna jaskini nie były już tak spójne (rys. 1) - 13\% ankietowanych zaznaczyło odpowiedź „nie wiem” lub nie zaznaczyło żadnej odpowiedzi, co stanowiło najwyższy odsetek takich odpowiedzi pośród wszystkich pytań o wiedzę naukową. Odpowiedź „ze skały wapiennej” wybrała największa grupa, stanowiąca $40 \%$ osób. $\mathrm{Z}$ naukowego punktu widzenia jest to odpowiedź niepoprawna, gdyż w przyotworowych partiach jaskiń rzadko się zdarza, żeby wapień odsłaniał się spod namuliska. A nawet w głęboko położonych korytarzach na dnie zazwyczaj występują osady ilaste bądź żwirowe. Drugą najczęściej wybieraną odpowiedzią było „zz ziemi lub gliny” i jest to odpowiedź najlepiej opisująca sytuację rzeczywistą. Dość duża grupa, bo 9\% ankietowanych, wybrała odpowiedź „z granitu lub bazaltu”. Jaskinie bazaltowe są faktycznie znane z obszarów wulkanicznych, ale to przypadki rzadkie, niewystępujące w Polsce, poza tym te jaskinie na ogół też mają namuliska. Duża grupa (10\%) sformułowała własne odpowiedzi na to pytanie; w czterech przypadkach stwierdzono, że budowa dna zależy od różnych czynników, takich jak „,typ jaskini / miejsce / skała, w której jaskinia się rozwinęła / od etapu rozwoju jaskini". Są to z całą pewnością odpowiedzi przemyślane i wskazujące na analityczne podejście ankietowanych do zadań. Według kolejnych czterech ankietowanych dno zbudowane jest z tej skały, w której rozwinęła się jaskinia, a trzech respondentów wskazało na osady jako budulec dna jaskini; były to odpowiedzi: "guano", „namulisko/wypełnisko” oraz „inne osady”. Pojawiła się również jedna odpowiedź „,z innej skały".

Jeszcze jednym sposobem na sprawdzenie znajomości obecności namulisk w jaskiniach było pytanie o kształt przekroju jaskini. Jako odpowiedzi do wyboru zaproponowano schematyczne rysunki pokazane na rysunku 1 . Na ankiecie pozostawiono również puste miejsce $z$ dopiskiem „jeśli przekrój jest inny, spróbuj go naszkicować" - odważyły się na to tylko trzy osoby (rys. 1). Oczywiście teoretycznie każdy z tych przekrojów 
Co to jest namulisko?

Brak odpowiedzi

Inna odpowiedź: stalaktyty, stalagmity, gruz, kości

Stalaktyty, stalagmity

Nie słyszałam/-em takiego określenia

Glina osadzona w jaskini

Muł namyty do jaskini, np. podczas powodzi

Z czego zbudowane jest dno jaskini?

Nie wiem

Brak odpowiedzi

Z granitu lub bazaltu

Inna odpowiedź: to zależy od skały / to zależy od miejsca / z innych skał

Z ziemi lub gliny

Ze skały wapiennej

Który rysunek przedstawia najbardziej rzeczywisty przekrój jaskini?

Brak odpowiedzi

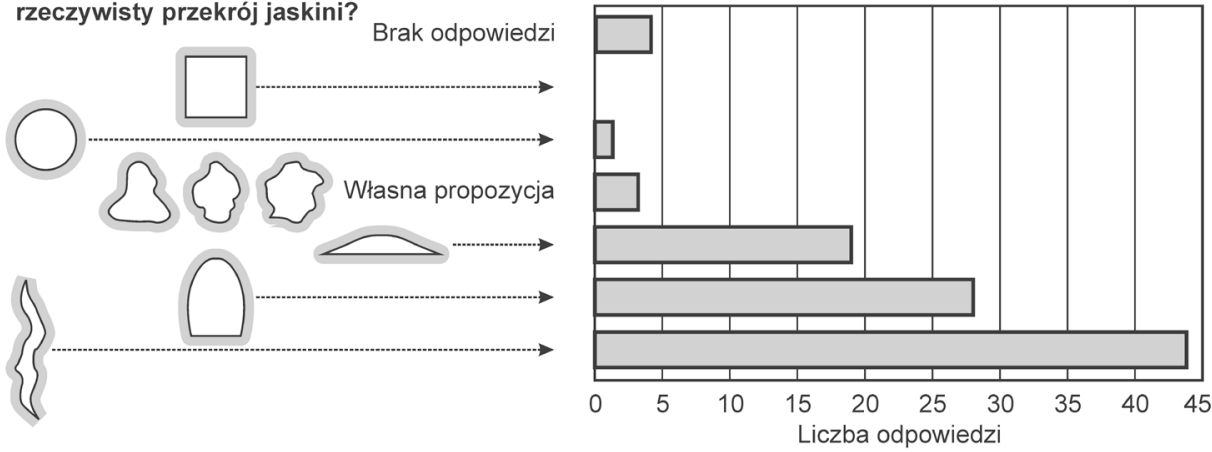

Rysunek 1. Odpowiedzi na zamieszczone w ankiecie pytania dotyczące namulisk jaskiniowych

Źródło: opracowanie własne na podstawie badania ankietowego przeprowadzonego w $2019 \mathrm{r}$.

może się pojawić w przyrodzie, ale występują one z różną częstością. Najmniej prawdopodobne są przekroje regularne, czyli pierwszy i drugi. Pierwszy jest ponadto typowym przekrojem sztolni kopalnianej. Typ piąty pojawia się w jaskiniach szczelinowych o wyraźnych założeniach tektonicznych. W przyotworowych partiach jaskiń, a więc tych najczęściej odwiedzanych przez turystów, spotyka się głównie podobne do siebie przekroje: trzeci i czwarty. Charakteryzują je obłe ściany i sklepienie, co jest typowe dla jaskiń pochodzenia krasowego, oraz płaskie dno, stanowiące powierzchnię namuliska. Co ciekawe, ponad połowa ankietowanych 
wybrała przekrój piąty, szczelinowaty. Przekroje trzeci i czwarty były kolejnymi najczęściej wybieranymi, zaznaczyło je odpowiednio 34\% i $23 \%$ ankietowanych. Niemal nikt nie zaznaczył przekroju pierwszego i drugiego. Wybór przekroju szczelinowatego jest o tyle zaskaku jący, że w większości jaskiń dostępnych dla ruchu turystycznego taka morfologia nie występuje lub występuje sporadycznie i na krótkich odcinkach. Należy sądzić, że wybór tego kształtu był podyktowany raczej tym, czego ludzie się spodziewają po jaskiniach, niż co faktycznie w nich obserwują. Być może takie wyobrażenie powstaje na skutek oglądania telewizyjnych filmów edukacyjnych, w których często pokazywane są głębokie partie jaskiń o takich właśnie kształtach, ze względu na ich atrakcyjność.

Podsumowując, uzyskane odpowiedzi prowadzą do wniosku, że znajomość budowy dna jaskini jest wśród ankietowanych słaba lub niepełna. W sytuacji, gdy większość jaskiń ma dna gliniaste, zaskakująca jest stosunkowo niska liczba takich odpowiedzi. Być może ponoszą za to winę chodniki budowane $\mathrm{w}$ jaskiniach $\mathrm{z}$ gruzu wapiennego lub cementu w udostępnionych dla ruchu turystycznego miejscach. Niewykluczone też, że część ankietowanych przez dno jaskini rozumiała skały podłoża położone pod namuliskiem i stąd częste odpowiedzi: „skała wapienna”, "granit lub bazalt” i „inna skała”. Nikt jednak nie zamieścił odpowiedzi lub dopisku, które potwierdzałyby takie rozumowanie.

\section{Wiedza o niedźwiedziu jaskiniowym}

Niedźwiedź jaskiniowy to wymarły gatunek, którego szczątki powszechnie występują w namuliskach jaskiniowych. W jaskiniach Wyżyny Krakowsko-Częstochowskiej udział kości tego gatunku często przekracza 90\%, można więc uznać go za najważniejsze ze zwierząt, których szczątki są spotykane w namuliskach (Wojtal, 2007). Duża liczba szczątków związana jest z tym, że niedźwiedzie wykorzystywały jaskinie jako miejsca hibernacji, a sen zimowy był okresem podwyższonej śmiertelności.

$\mathrm{W}$ ankiecie zamieszczono dwa pytania dotyczące niedźwiedzia jaskiniowego, m.in. w celu sprawdzenia, czy ten gatunek jest w ogóle znany. Posłużyło temu pytanie „,które z tych zwierząt istnieją lub istniały naprawdę?", z zamieszczonymi ośmioma nazwami zwierząt do wyboru, zawierającymi słowo ,jjaskiniowy". Wśród możliwych odpowiedzi znalazły się zarówno gatunki wymarłe (niedźwiedź jaskiniowy, lew jaskiniowy, hiena jaskiniowa), współczesne (ślepiec jaskiniowy, odmieniec jaskiniowy), jak i zupełnie zmyślone (mamut jaskiniowy, mysz jaskiniowa i leniwiec 
jaskiniowy). Analiza zaznaczonych odpowiedzi (rys. 2) stanowi interesujące studium samo w sobie. Koncentrując się jednak na niedźwiedziu jaskiniowym, trzeba zwrócić uwagę, że był on najczęściej wybierany z proponowanych odpowiedzi. Zaznaczyło go aż 58 ankietowanych, co stanowi $2 / 3$ przebadanych osób. Odpowiedź ta ponad trzykrotnie przewyższała drugą najczęściej wybierana, którą był „ślepiec jaskiniowy”. Wysokie miejsce ślepca $\mathrm{w}$ rankingu może wynikać $\mathrm{z}$ faktu, że ryba ta jest wspominana w szkolnych podręcznikach biologii jako przykład przystosowania do skrajnych warunków. Uzyskane wyniki pokazują że niedźwiedź jaskiniowy jest gatunkiem dobrze znanym, przynajmniej z nazwy.

Drugie pytanie dotyczyło genezy nagromadzeń kości niedźwiedzia jaskiniowego. Pytanie miało formę: „dlaczego w jaskiniach znajduje się

Które z tych zwierząt istniały lub istnieją naprawdę?

Leniwiec jaskiniowy
Odmieniec jaskiniowy
Mamut jaskiniowy
Mysz jaskiniowa
Lew jaskiniowy
Hiena jaskiniowa
Ślepiec jaskiniowy
Niedźwiedź jaskiniowy

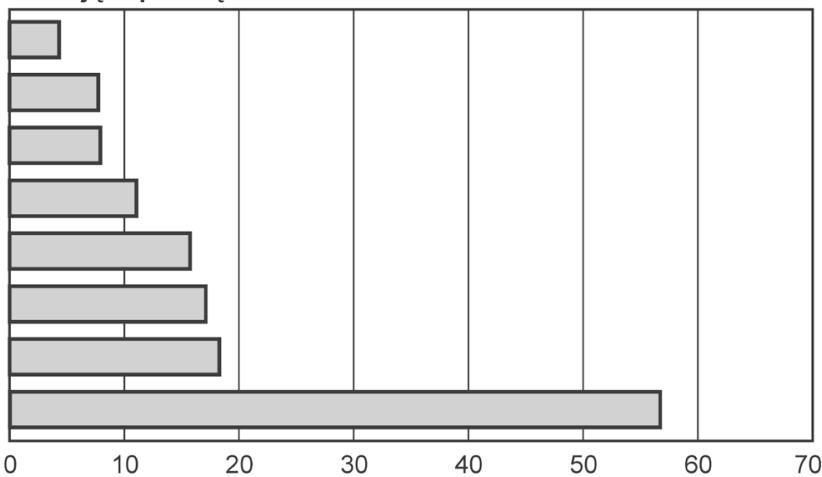

Dlaczego w jaskiniach znajdują się kości niedźwiedzi?

Brak odpowiedzi

Nie wiem

Inna odpowiedź: nie ma kości niedźwiedzi w jaskiniach

Inna odpowiedź: zdechły, niekoniecznie podczas snu zimowego

Inna odpowiedź: przyniesione przez wodę

Inna odpowiedź: przyniesione przez ludzi

Zostały tam zakopane

Zostały tam zabite

Zdechły podczas snu zimowego

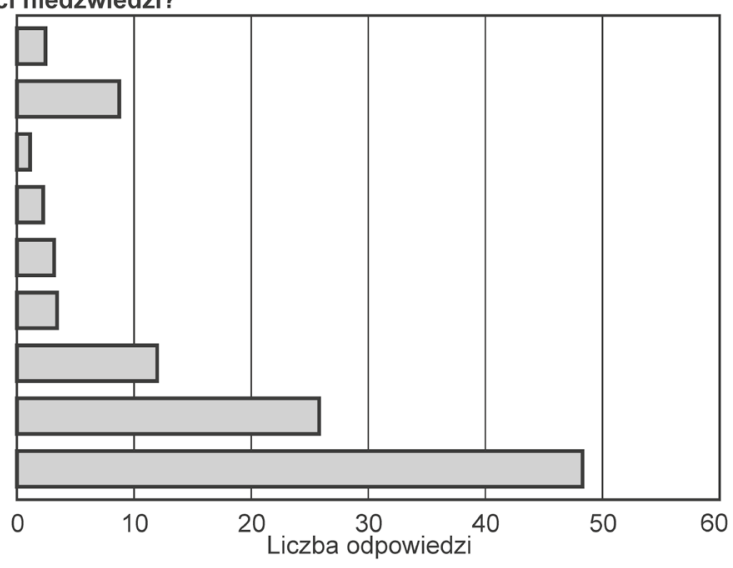

Rysunek 2. Odpowiedzi ankietowanych na pytania dotyczące niedźwiedzia jaskiniowego

Źródło: opracowanie własne na podstawie badania ankietowego przeprowadzonego w $2019 \mathrm{r}$. 
kości niedźwiedzi?”. Aż 64\% ankietowanych udzieliło poprawnej z naukowego punktu widzenia odpowiedzi: „,bo zdechły podczas snu zimowego" (rys. 2). Dodatkowo pojawiły się dwie odpowiedzi własne, będące rozwinięciem powyższej: „bo zdechły tam, niekoniecznie podczas snu zimowego". Kolejną najczęściej wybieraną odpowiedzią było „bo zostały tam zabite" i „,bo zostały tam zabite lub przyniesione przez ludzi”. Być może pokutuje tu dawna interpretacja archeologa, prof. W. Chmielewskiego, co do znaczenia struktur odkrytych w Jaskini Nietoperzowej (Chmielewski, 1975). Nagromadzenia węgla drzewnego i krzemiennych grotów tłumaczył on jako formę pułapki na niedźwiedzie, złożonej z ognisk, które miały je wykurzyć z jaskini, i zasieków z włóczni, w które miały wpaść lub którymi miały być dźgane przez myśliwych. Nie da się potwierdzić słuszności tej hipotezy, w każdym razie tłumaczyłaby ona tylko jednostkowy przypadek. Interpretacja ta jest jednak przedstawiana turystom zwiedzającym Jaskinię Nietoperzową przez przewodników, co może wpływać na przekonanie wielu osób o takich właśnie powodach śmierci niedźwiedzi jaskiniowych. Ponadto 12 osób zaznaczyło odpowiedź „bo zostały tam zakopane”, a 3 osoby zaproponowały własną wersję: „, bo zostały tam naniesione przez wodę". Pierwsza z tych odpowiedzi ma raczej niewiele wspólnego ze stanem faktycznym. Natomiast redepozycja kości przez płynącą wodę jest znana np. z niektórych partii Jaskini Niedźwiedziej (Wiszniowska, 1989) i być może jej zwiedzanie skutkowało nabyciem takiej wiedzy przez ankietowanych.

\section{Wnioski}

Analiza ankiet pokazuje, że respondenci mają bardzo dobrą wiedzę ogólną o jaskiniach. Duży wskaźnik odpowiedzi twierdzących na pytanie „czy bałaś/-eś kiedyś w jaskini?" wskazuje, że niebagatelną rolę odgrywa tu zapewne turystyka krajoznawcza. Większość ankietowanych potrafi wymienić nazwę co najmniej jednej jaskini z Polski, ma wiedzę dotyczącą genezy jaskiń i skał, w jakich się tworza, oraz występowania i budowy szaty naciekowej, a także na temat datowania pradziejowego osadnictwa w jaskiniach. Znacznie gorzej przedstawia się znajomość budowy namulisk jaskiniowych. Sam termin jest słabo znany i raczej kojarzony z procesami namywania. Odwiedzanie jaskiń nie przyczynia się do zdobywania informacji o namuliskach, gdyż z racji swego położenia i nietrwałości są one słabo wyeksponowane na trasach turystycznych. Korzystnym działaniem dla krajoznawstwa i zwiększania wiedzy wśród zwiedzających 
byłoby uatrakcyjnienie osadów jaskiniowych poprzez ich sztuczne wyeksponowanie. Oznacza to udostępnienie do zwiedzania w ważnych turystycznie jaskiniach wykopów obrazujących budowę namuliska bądź interesujących znalezisk pochodzących z tych osadów. Niezależnie od tego czy prezentowane będą rzeczywiste obiekty, czy ich odwzorowania (np. filmy, fotografie, hologramy, odlewy), przygotowanie ich wymaga znacznych nakładów pracy oraz zmian organizacyjnych w zakresie sposobu udostępniania jaskiń. Niezbędna wydaje się także współpraca środowisk turystyczno-oświatowych i naukowych, a być może również biznesowych.

Analiza ankiet pokazuje, że respondenci mają wiedzę dotyczącą konkretnych obiektów jaskiniowych, która daje pewne ogólne wyobrażenie o jaskiniach. Tak może być np. w przypadku zabijania niedźwiedzi jaskiniowych przez prehistorycznych ludzi w Jaskini Nietoperzowej lub kości redeponowanych przez wodę w Jaskini Niedźwiedziej. Za utrwalanie tej wiedzy odpowiadają zapewne przewodnicy oprowadzający po jaskiniach. Pełnią oni bardzo ważną rolę w upowszechnianiu wiedzy o jaskiniach, ale czasem dysponują informacjami, które mają charakter hipotez. Należy zwracać na to baczniejszą uwagę podczas szkolenia przewodników.

\section{Podziękowania}

Pragnę złożyć serdeczne podziękowania wszystkim respondentom oraz osobom, które zaoferowały pomoc w rozprowadzaniu ankiet. W szczególności dziękuję Panu dr. Józefowi Partyce, Pani prof. dr hab. Teresie Madeyskiej i Pani prof. dr hab. Krystynie Szeroczyńskiej.

\section{Bibliografia}

Chmielewski, W. (1975). Paleolit środkowy i górny. W: W. Chmielewski, W. Hensel (red.), Prahistoria ziem polskich. Tom I: Paleolit i Mezolit (s. 9-158). Wrocław-WarszawaKraków-Gdańsk: Zakład Narodowy im. Ossolińskich, Wydawnictwo Polskiej Akademii Nauk.

Encyklopedia PWN (2021). Jaskinia. Pobrane z: https:/encyklopedia.pwn.pl/haslo/jaskinia;3917165.html (24.02.2021).

Krukowski, S. (1939-1948). Paleolit. W: S. Krukowski, J. Kostrzewski, R. Jakimowicz (red.), Prehistoria ziem polskich. Encyklopedia Polska. Tom IV (s. 1-117). WarszawaKraków-Łódź-Poznań-Zakopane: Polska Akademia Umiejętności. 
Madeyska, T. (1988). Osady jaskiń i schronisk Doliny Sąspowskiej. W: W. Chmielewski (red.), Jaskinie Doliny Sąspowskiej. Tło przyrodnicze osadnictwa pradziejowego (s. 77-173). Warszawa: Prace Instytutu Archeologii UW, Wydawnictwo Uniwersytetu Warszawskiego.

Madeyska-Niklewska, T. (1969). Górnoplejstoceńskie osady jaskiń Wyżyny Krakowskiej. Acta Geologica Polonica, 19, 341-390.

Migoń, P. (2006). Geomorfologia. Warszawa: Wydawnictwo Naukowe PWN.

Szelerewicz, M., Górny, A. (1986). Jaskinie Wyżyny Krakowsko-Wieluńskiej. WarszawaKraków: Wydawnictwo PTTK „Kraj”.

Wiszniowska, T. (1989). Kopalne szczątki zwierzęce. W: A. Jahn, S. Kozłowski, T. Wiszniowska (red.), Jaskinia Niedźwiedzia w Kletnie. Badania i udostępnianie (s. 255-279). Wrocław-Warszawa-Kraków-Gdańsk-Łódź: Zakład Narodowy im. Ossolińskich, Wydawnictwo Polskiej Akademii Nauk.

Wojtal, P. (2007). Zooarchaeological studies of of the late Pleistocene sites in Poland. Kraków: Institute of Systematics and Evolution of Animals, Polish Academy of Sciences.

\title{
NAMULISKA JASKINIOWE \\ WE WSPÓŁCZESNYM KRAJOZNAWSTWIE POLSKIM - SPOŁECZNA ZNAJOMOŚĆ ZAGADNIENIA
}

\begin{abstract}
Abstrakt: Ważną rolę w krajoznawstwie turystycznym pełnią jaskinie. Niektóre z nich są chętnie odwiedzane przez turystów ze względu na ciekawą szatę naciekowa, możliwość zobaczenia nietoperzy, urok podziemnych korytarzy oraz aurę tajemniczości. Z naukowego punktu widzenia szczególnie ważnym elementem jaskiń są namuliska - czyli wypełniające je serie osadów okruchowych. Mają one znaczenie dla poznania historii i prehistorii zasiedlania jaskiń i ich okolic przez ludzi, ale również dla poznania historii fauny i flory, procesów geologicznych odpowiadających za nagromadzenie osadów, oraz zmian klimatycznych. W niniejszym opracowaniu podjęto próbę ewaluacji znaczenia namulisk w krajoznawstwie jaskiniowym. Ustalono również, czy sam termin „namulisko" lub idea, którą wyraża, są znane w społeczeństwie. Następnie, w jaki sposób - jeśli w ogóle - namuliska jaskiniowe są postrzegane przez turystów i które aspekty wiedzy o namuliskach są im znane. Analizowano tę wiedzę turystów w kontekście ich ogólnego zasobu wiadomości o jaskiniach. Badania przeprowadzone zostały za pomocą anonimowych ankiet, rozprowadzanych wśród różnych grup społecznych, takich jak uczniowie, studenci, nauczyciele, turyści.
\end{abstract}

Słowa kluczowe: jaskinie, turystyka jaskiniowa, edukacja, wiedza geograficzna, speleologia.

\section{CAVE DEPOSITS IN CONTEMPORARY POLISH SIGHTSEEING: SOCIAL AWARENESS OF THIS ISSUE}

\begin{abstract}
Caves play an important role in tourist sightseeing. Some of them are eagerly visited by tourists due to the beautiful speleothems, the opportunity to see bats, the charm of underground passages and the aura of mystery. From the academic point of view, a particularly important element of caves is their deposits - the series of clastic sediments filling a cave cavity. They constitute an important source of information about the history and prehistory of human settlement in caves and their surroundings, and also the
\end{abstract}


history of fauna and flora, the geological processes responsible for the accumulation of sediments and climate change. In this study, an evaluation of the importance of cave deposits to cave tourism is attempted, whether the Polish term "namulisko" (cave deposits) itself or the idea it expresses, is known in the public, and also how cave deposits are perceived by tourists, if at all, and which aspects are known. There was an attempt at recognition of this among tourists in the context of their general knowledge about caves. The research was carried out using anonymous questionnaires distributed among various social groups such as school and university students, teachers and tourists.

Keywords: caves, cave tourism, education, geographic knowledge, speleology. 